\title{
Editorial: Illegal Fishing as a Trans-National Crime
}

\author{
Dyhia Belhabib ${ }^{1}$ and Philippe Le Billon ${ }^{2 *}$ \\ ${ }^{1}$ EcoTrust Canada, Vancouver, BC, Canada, ${ }^{2}$ Department of Geography, School of Public Policy and Global Affairs, \\ University of British Columbia, Vancouver, BC, Canada
}

Keywords: Illegal fishing, organized crime, IUU, slavery, corruption, trafficking

\section{Editorial on the Research Topic}

\section{Illegal Fishing as a Trans-National Crime}

Illegal fishing is a widespread phenomenon with broad socio-environmental impacts and transnational criminal dimensions. Ubiquitous, illegal fishing has been reported across all regions of the world, with hotspots in West and East Africa, North Pacific, and South East Asia (see online reporting platform Spyglass.fish). Illegal fishing together with unreported and unregulated practices (IUU) accounted for nearly a quarter of the $\$ 120$ billion global landed value of fisheries in 2016 (Pauly and Zeller, 2016). The transnational dimensions of illegal fishing include vessels illegally fishing outside their home country, affected fish stocks crossing national EEZ, globalized seafood supply chains processing and retailing illegally harvested fish, and IUU vessel involvement in other transnational crimes such as drug trafficking (Chapsos and Hamilton, 2019).

Illegal fishing negatively impact fish stocks (Le Gallic and Cox, 2006) and ecosystems (Pascoe

\section{OPEN ACCESS}

Edited by:

Athanassios C. Tsikliras, Aristotle University of

Thessaloniki, Greece

Reviewed by:

Paraskevi K. Karachle, Hellenic Center for Marine Research, Greece

*Correspondence:

Philippe Le Billon

lebillon@geog.ubc.ca

Specialty section:

This article was submitted to Marine Fisheries, Aquaculture and

Living Resources,

a section of the journal

Frontiers in Marine Science

Received: 23 December 2019 Accepted: 02 March 2020 Published: 19 March 2020

Citation:

Belhabib D and Le Billon P (2020)

Editorial: Illegal Fishing as a

Trans-National Crime.

Front. Mar. Sci. 7:162.

doi: 10.3389/fmars.2020.00162 et al., 2008), including through overharvesting and prohibited gear usage, with increased risk of stock collapse and species extinction, reshaped marine food webs, and reduction of climate resilience for both fish stocks and fishing communities (Konar et al., 2019). Fish stocks overexploitation increase fishing costs, poverty among small-scale fishers, and human rights abuses including slavery aboard ships become more common (Kittinger et al., 2017; Tickler et al., 2018; Teh et al., 2019). Societal and economic losses are far reaching, as IUU fishing results in loss of employment (Daniels et al., 2016), and economic opportunity (Agnew et al., 2009), loss of income and tax revenue (Konar et al., 2019), and international maritime conflicts (OECD, 2004; Sumaila and Bawumia, 2014; Pomeroy et al., 2016; Standing, 2017; Belhabib et al., 2019; Spijkers et al., 2019). As Glaser et al. shows, foreign IUU fishing in Somali waters fuels public anger and perpetuates conflict with foreign vessels by directly competing with the domestic fishery, destroying bottom ecosystems, aggravating tensions over vessel licensing and contributing to piracy. Illegal fishing can also undermine communities' social cohesion and coastal stewardship, with profound losses in vulnerable low income regions dependent on fish for their employment and food security (Le Gallic and Cox, 2006).

The criminal dimensions of illegal fishing include both fisheries related crimes such as enforcement evasion, misreporting, document forging, money laundering, labor abuses, and tax evasion (OECD, 2013), but also crimes associated with the fisheries sector, including piracy (Denton and Harris, 2019) and various types of trafficking (UNODC, 2011; Vrancken et al., 2019). Complex corporate ownership networks, numerous jurisdictional layers between the companies and vessels, along with common changes in vessel color, name and flag state constitute elaborate evasion techniques that significantly jeopardize vessel apprehension (Österblom, 2014; Belhabib and Le Billon, 2018; Galaz et al., 2018). Miller et al. find that transshipment at sea, particularly in the high seas, is rampant and frequently associated with human rights abuses (such as slavery), requiring more global action and monitoring outside EEZs. As a fraudulent, organized, and transnational activity (Österblom et al., 2011; UNODC, 2011), IUU also lends itself to other illegal activities including the trafficking of 
drugs, migrants, weapons, and wildlife (Phelps Bondaroff et al., 2015; Kittinger et al., 2017). There is a growing body of evidence that suggest that illegal fishing is interlinked with various types of transnational crimes, particularly in spaces with low environmental enforcement at sea (Sumaila et al., 2006; Doumbouya et al., 2017), high corruption levels both on land and at sea (Erdmann, 2001; Standing, 2008; Hanich and Tsamenyi, 2009; Martini, 2013; Sumaila et al., 2017), and weak governance (Standing, 2008).

Root causes of illegal fishing including cost/benefit analysis by offenders (Becker, 1968), but also moral, societal, economic, and cultural factors affecting behaviors-including feelings of entitlement or ownership over the resource, protest against existing rules (Sutinen and Kuperan, 1999), resistance to impoverishing exclusionary conservation (Sutinen and Kuperan, 1999; Sumaila et al., 2006; Belhabib, in review), coercive enrollment (Andrews-Chouicha and Gray, 2005), as well as the hold of organized crime and moral norms within fishing communities (Le Gallic and Cox, 2006; Österblom et al., 2011; Belhabib and Le Billon, 2018; Galaz et al., 2018), regardless of deterrence levels and sanction risks (Sutinen and Kuperan, 1999). Overcapacity, ineffective management and subsidies can exacerbate illicit fishing (Le Gallic and Cox, 2006), alongside poverty and economic desperation, especially in contexts of crisis (Couper et al., 2015).

So far, regulatory efforts targeting IUU fishing mostly seek to detect and prosecute fisheries management offenses through vessel monitoring, control and surveillance (MCS), but often disregard other types of crimes committed onboard fishing vessels or by fishing companies that are criminal and should be prosecuted as such (UNODC, 2011, 2017; Doumbouya et al., 2017). Economic losses can be massive for affected countries, as demonstrated by Intchama et al. in the case of Guinea Bissau, but more effectiveness of monitoring control and surveillance,

\section{REFERENCES}

Agnew, D. J., Pearce, J., Pramod, G., Peatman, T., Watson, R., Beddington, J. R., et al. (2009). Estimating the worldwide extent of illegal fishing. PLoS ONE 4:e4570. doi: 10.1371/journal.pone.0004570

Andrews-Chouicha, E., and Gray, K. (2005). Why Fish Piracy Persists: The Economics of Illegal, Unreported, and Unregulated Fishing. Organisation for Economic Co-operation and Development.

Becker, G. S. (1968). Crime and punishment: an economic approach. J. Polit. Econ. 76, 169-217. doi: 10.1086/259394

Belhabib, D., and Le Billon, P. (2018). Tax havens are the tip of the iceberg. Nat. Ecol. Evol. 2:1679. doi: 10.1038/s41559-018-0704-2

Belhabib, D., Sumaila, U. R., and Le Billon, P. (2019). The fisheries of Africa: exploitation, policy, and maritime security trends. Mar. Policy 101, 80-92. doi: 10.1016/j.marpol.2018.12.021

Cabral, R. B., Mayorga, J., Clemence, M., Lynham, J., Koeshendrajana, S., and Gaines, S. D. (2018). Rapid and lasting gains from solving illegal fishing. Nat. Ecol. Evol. 2, 650-658. doi: 10.1038/s41559-018-0499-1

Chapsos, I., and Hamilton, S. (2019). Illegal fishing and fisheries crime as a transnational organized crime in Indonesia. Trends Org. Crime 22, 255-273. doi: 10.1007/s12117-018-9329-8

Couper, A., Smith, H. D., and Ciceri, B. (2015). Fishers and Plunderers: Theft, Slavery and Violence at Sea. London: Pluto Press. doi: 10.2307/j.ctt183p451 as well as more drastic interdiction measures as seen recently in Indonesia, can help reduce them (Cabral et al., 2018). Major fishing countries, especially those with large distant fishing fleets, should severely punish illegal fishing by their own vessels and companies, prevent vessel re-flagging, and track beneficial owners (Telesetsky, 2014). Measures targeting fishing subsidies (Sumaila et al., 2016), marine insurance (Miller et al., 2016), oil bunkering activities (Ford et al., 2018), flag-hopping (Miller and Sumaila, 2016), and connections with organized crime in related sectors (Phelps Bondaroff et al., 2015). International regulatory cooperation and harmonization are also crucial to tackle the transnational dimensions of illegal fishing. Using an economic risk index for the EU carding system seeking to reducing IUU, Sumailas demonstrates that the participation of a critical mass of top fish importing countries is necessary for an IUU carding system to have a significant effect on the elimination of IUU fishing. Current knowledge on IUU vessels (Galaz et al., 2018) limits information to spotlight areas and creates a systemic coverage bias (Belhabib and Le Billon, 2018), therefore requiring more comprehensive information gathering and analyzing the full scope of transnational crimes associated with illegal fishing. Authorities should not simply respond to illegal fishing through fishery management, but address its many transnational criminal dimensions.

\section{AUTHOR CONTRIBUTIONS}

All authors listed have made a substantial, direct and intellectual contribution to the work, and approved it for publication.

\section{FUNDING}

This work was supported by Social Sciences and Humanities Research Council, Canada.
Daniels, A., Gutierrez, M., Fanjul, G., Guerena, A., Matheson, I., and Watkins, K. (2016). Western Africa's Missing Fish. The Impacts of Unreported and Unregulated Fishing and Under-Reporting Catches by Foreign Fleets. Overseas Development Institute, London.

Denton, G. L., and Harris, J. R. (2019). The impact of illegal fishing on maritime piracy: evidence from West Africa. Stud. Confl. Terror. doi: 10.1080/1057610X.2019.1594660. [Epub ahead of print].

Doumbouya, A., Camara, O. T., Mamie, J., Intchama, J. F., Jarra, A., Ceesay, S., et al. (2017). Assessing the effectiveness of monitoring control and surveillance of illegal fishing: the case of West Africa. Front. Mar. Sci. 4:50. doi: 10.3389/fmars.2017. 00050

Erdmann, M. V. (2001). Who's minding the reef? Corruption and enforcement in Indonesia. SPC Live Fish Inf. Bull. 8, 19-20.

Ford, J. H., Bergseth, B., and Wilcox, C. (2018). Chasing the fish oil-do bunker vessels hold the key to fisheries crime networks?. Front. Mar. Sci. 5:267. doi: 10.3389/fmars.2018.00267

Galaz, V., Crona, B., Dauriach, A., Jouffray, J.-B., and Österblom, H., Fichtner, J. (2018). Tax havens and global environmental degradation. Nat. Ecol. Evol. 2, 1352-1357. doi: 10.1038/s41559-018-0497-3

Hanich, Q., and Tsamenyi, M. (2009). Managing fisheries and corruption in the Pacific Islands region. Mar. Policy 33, 386-392. doi: 10.1016/j.marpol.2008.08.006 
Kittinger, J. N., Teh, L. C. L., Allison, E. H., Bennett, N. J., Crowder, L. B., and Finkbeiner, E. M. (2017). Committing to socially responsible seafood. Science 356, 912-913. doi: 10.1126/science.aam 9969

Konar, M., Gray, E., Thuringer, L., and Sumaila, U. R. (2019). The Scale of Illicit Trade in Pacific Ocean Marine Resources (Working Paper). Washington, DC: World Resources Institute.

Le Gallic, B., and Cox, A. (2006). An economic analysis of illegal, unreported and unregulated (IUU) fishing: key drivers and possible solutions. Mar. Policy 30, 689-695. doi: 10.1016/j.marpol.2005.09.008

Martini, M. (2013). Illegal, Unreported and Unregulated Fishing and Corruption, Expert Answer. Transparency International.

Miller, D. D., and Sumaila, U. R. (2016). "IUU fishing and impact on the seafood industry," in Seafood Authenticity and Traceability, eds A. M. Naaum and R. H. Hanner (Cambridge, MA: Academic Press), 83-95. doi: 10.1016/B978-0-12-801592-6.00004-8

Miller, D. D., Sumaila, U. R., Copeland, D., Zeller, D., and Pauly, D. (2016). Cutting a lifeline to maritime crime: marine insurance and IUU fishing. Front. Ecol. Environ. 14, 357-362. doi: 10.1002/fee.1293

OECD (2004). Fish Piracy Combating Illegal, Unreported and Unregulated Fishing: Combating Illegal, Unreported and Unregulated Fishing. Organisation for Economic Co-operation and Development.

OECD (2013). Evading the Net: Tax Crime in the Fishing Sector. Organisation for Economic Co-operation and Development.

Österblom, H. (2014). Catching up on fisheries crime. Conserv. Biol. 28, 877-879. doi: $10.1111 /$ cobi.12229

Österblom, H., Constable, A., and Fukumi, S. (2011). Illegal fishing and the organized crime analogy. Trends Ecol. Evol. 26, 261-262. doi: $10.1016 /$ j.tree.2011.03.017

Pascoe, S., Okey, T. A., and Griffiths, S. (2008). Economic and ecosystem impacts of illegal, unregulated and unreported (IUU) fishing in Northern Australia. Aust. J. Agric. Resour. Econ. 52, 433-452. doi: 10.1111/j.1467-8489.2008.0 0420.x

Pauly, D., and Zeller, D. (2016). Catch reconstructions reveal that global marine fisheries catches are higher than reported and declining. Nat. Commun. 7:10244. doi: $10.1038 /$ ncomms 10244

Phelps Bondaroff, T. N., van der Werf, W., and Reitano, T. (2015). The Illegal Fishing and Organized Crime Nexus: Illegal Fishing as Transnational Organized Crime. Geneva: Global Initiative against Transnational Crime.

Pomeroy, R., Parks, J., Mrakovcich, K. L., and LaMonica, C. (2016). Drivers and impacts of fisheries scarcity, competition, and conflict on maritime security. Mar. Policy 67, 94-104. doi: 10.1016/j.marpol.2016.01.005

Spijkers, J., Singh, G., Blasiak, R., Morrison, T. H., Le Billon, P., and Österblom, H. (2019). Global patterns of fisheries conflict: forty years of data. Global Environ. Change 57:101921. doi: 10.1016/j.gloenvcha.2019.05.005

Standing, A. (2008). Corruption and Industrial Fishing in Africa. U4 Issue.

Standing, A. (2017). Criminality in Africa's Fishing Industry: A Threat to Human Security. Afr. Secur. Briefs 1.
Sumaila, U. R., Alder, J., Keith, H. (2006). Global scope and economics of illegal fishing. Mar. Policy 30, 696-703. doi: 10.1016/j.marpol.2005.11.001

Sumaila, U. R., Bawumia, M. (2014). Fisheries, ecosystem justice and piracy: a case study of Somalia. Fish. Res. 157, 154-163. doi: 10.1016/j.fishres.2014.04.009

Sumaila, U. R., Jacquet, J., Witter, A. (2017). "When bad gets worse: corruption and fisheries," in Corruption Natural Resources and Development: From the Resource Curse to Political Ecology, eds A. Williams and P. Le Billon (Cheltenham: Edward Elgar), 93-105. doi: 10.4337/9781785361203. 00015

Sumaila, U. R., Lam, V., Le Manach, F., Swartz, W., and Pauly, D. (2016). Global fisheries subsidies: an updated estimate. Mar. Policy 69, 189-193. doi: 10.1016/j.marpol.2015. 12.026

Sutinen, J. G., Kuperan, K. (1999). A socio-economic theory of regulatory compliance. Int. J. Soc. Econ. 26, 174-193. doi: 10.1108/03068299910229569

Teh, L. C. L., Caddell, R., Allison, E. H., Finkbeiner, E. M., Kittinger, J. N., Nakamura, K., et al. (2019). The role of human rights in implementing socially responsible seafood. PLoS ONE 14:e0210241. doi: 10.1371/journal.pone.0210241

Telesetsky, A. (2014). Laundering fish in the global undercurrents: Illegal, unreported, and unregulated fishing and transnational organized crime. Ecology 41, 939.

Tickler, D., Meeuwig, J. J., Bryant, K., David, F., Forrest, J. A., Gordon, E., et al. (2018). Modern slavery and the race to fish. Nat. Commun. 9, 1-9. doi: 10.1038/s41467-018-07118-9

UNODC (2011). Transnational Organized Crime in the Fishing Industry. Focus on: Trafficking in Persons, Smuggling of Migrants, Illicit Drugs Trafficking. Vienna: United Nations Office on Drugs and Crime.

UNODC (2017). Fisheries Crime. Vienna: United Nations Office on Drugs and Crime.

Vrancken, P., Witbooi, E., and Glazewski, J. (2019). Introduction and overview: transnational organised fisheries crime. Mar. Policy, 105, 116-122. doi: 10.1016/j.marpol.2018.12.016

Conflict of Interest: DB is principal investigator of Spyglass.com, a platform tracking the criminal record of fishing vessels.

The remaining author declares that the research was conducted in the absence of any commercial or financial relationships that could be construed as a potential conflict of interest.

Copyright (c) 2020 Belhabib and Le Billon. This is an open-access article distributed under the terms of the Creative Commons Attribution License (CC BY). The use, distribution or reproduction in other forums is permitted, provided the original author(s) and the copyright owner(s) are credited and that the original publication in this journal is cited, in accordance with accepted academic practice. No use, distribution or reproduction is permitted which does not comply with these terms. 